\title{
Molecular detection and Characterization of Merkle Cell Polyoma Virus in Lymphomas among Sudanese Patients
}

\author{
Mohammed A Ibrahim ${ }^{1}$, Khalid A Enan ${ }^{1}$, Abdel Rahim M El Hussein ${ }^{1}$, Mohamed O Mustafa ${ }^{1}$, Bashir Salim², \\ Isam M Elkhidir ${ }^{3}$ \\ ${ }^{1}$ Department of Virology, Central Laboratory, Ministry of Higher Education and Scientific Research, Khartoum, Sudan \\ ${ }^{2}$ Department of Parasitology, Faculty of Veterinary Medicine, University of Khartoum, P.O. Box 32, Khartoum North, \\ Sudan \\ ${ }^{3}$ Department of Microbiology and Parasitology, Faculty of Medicine, University of Khartoum, Sudan
}

\begin{abstract}
Objectives: Lymphoma (Hodgkin and Non-Hodgkin) is one of the most common malignancies in Sudan. Contemporaneous studies from several countries including the United States, Japan and Germany suggested a possible etiological link between Merkle cell polyoma virus (MCPyV) and these lymphomas; however, there are no previous studies that have been reported on this topic in Sudan. This study was applied to investigate the role of this virus in lymphoma patients in Sudan. Objective is to detect and characterize Merkle Cell Polyomavirus in lymphoma patients by using molecular techniques
\end{abstract}

Method: Adult Sudanese patients (both females and males) diagnosed with lymphoma were included in this study. Blood samples were used for DNA extraction which was then subjected to Real-time PCR to detect MCPyV DNA. Samples, proved positive by Real-time PCR amplification, were sequenced and phylogenetically analyzed.

Results: MCPyV was detected in 16/225 from Sudanese (7.1\%) of lymphoma patients of which five were Hodgkin and eleven were Non-Hodgkin. MCPyV sequences in Sudanese patients showed $100 \%$ similarity to each other and $100 \%$ identity with reference sequences from gene bank.

Conclusion: This study is the first evidence that MCPyV exists in a subset of Sudanese lymphoma patients. MCPyV is unlikely to have direct contribution in the pathogenesis of lymphoma in the majority of Sudanese cases. MCPyV identified from the Sudanese lymphoma subjects may constitute an African lineage and its pathogenicity needs to be investigated in future studies. J Microbiol Infect Dis 2020; 10(1):47-52.

Keywords: Merkle Cell Polyomavirus, Hodgkin Lymphoma, Non-Hodgkin, Real-time PCR, Sudan

\section{INTRODUCTION}

Polyomaviruses are double stranded DNA, icosahedral, non-enveloped viruses. Their circular genome encodes certain oncogenic proteins; thus, they are considered as putative oncogenic viruses [1,2]. Currently, there are nine recognized human polyomaviruses but their roles in carcinogenesis are not well understood [3]. The fifth polyomavirus; Merkle cell polyomavirus (MCPyV); was reported in 2008 [4]. This virus was detected in approximately
$80 \%$ of Merkle cell carcinoma (MCCs) which is an aggressive skin carcinoma. More recently Human polyomavirus 9 (HPyV9) was identified in the serum of kidney transplant patients who were undergoing immunosuppressive treatment [5]. MCPyV is phylogenetically closely related to the African green monkey-derived lymphotropic polyomavirus which is capable of infecting lymphoid cells [6]. The search for hematologic neoplasia's where MCPyV may have a role in its pathogenesis is at present an active area of

Correspondence: Khalid A Enan, Department of Virology, Central Laboratory, The Ministry of Higher Education and Scientific Research, Khartoum, Sudan

E-mail: khalid_enan@hotmail.com

Received: 20 November 2019 Accepted: 09 January 2020

Copyright (C JMID / Journal of Microbiology and Infectious Diseases 2020, All rights reserved 
research [7]. The possible association of MCPyV with lymphoid malignancies was first recorded by researchers from USA, but they did not find a significant association between CLL and MCPyV $[8,9]$. However, researchers from Canada and Germany were able to detect MCPyV-positive CLL cases and advocated the possible involvement of MCPyV in a subset of CLLs $[10,11]$. More recently, another group of researchers from USA also reported MCPyVpositive CLLs [12].

\section{METHODS}

\section{Clinical specimens}

Whole blood samples (225) were obtained from lymphoma patients ( 140 were $\mathrm{HL}$ and 85 were $\mathrm{NHL}$ ) during the period April 2015 to September 2015. About $7 \mathrm{ml}$ of EDTA venous blood was collected, of which $2 \mathrm{ml}$ were used for full blood count. The rest of the blood was used for DNA extraction.

\section{DNA preparation}

Commercial DNA extraction kits (Analytikjena, Germany) were used to extract DNA of MCPyV from 200 microliter whole blood samples according to procedure described by the manufacturer.

\section{Real-time PCR for MCPyV}

Real-time one-step RT-PCR for the LT regions of MCPyV was carried out to detect viral DNA by using a commercial kit according to the manufacturer's directions (Real-Time RT-PCR kit, Analytikjena, Germany) Real-time-PCR was carried out by using primers/probe as shown in Table 1 for MCPyV LT regions [13].

The master mix for single real time PCR reaction was prepared as follows: $10 \mu \mathrm{l}$ of $2 \mathrm{X}$ PCR reaction mix, $1 \mu \mathrm{l}$ of each primer forward and reverse / 0.5 probe, $2.5 \mu \mathrm{l}$ of molecular grade water, and $5 \mu \mathrm{l}$ of total DNA. The final volume was $25 \mu \mathrm{l}$ for a single reaction (Analytikjena, Germany). The reaction was performed in Roter gene Q (Qiagen, Germany). The thermal cycling conditions were 2 minutes at $95{ }^{\circ} \mathrm{C}$ for initial denaturation and 45 cycles of 15 seconds at 95 ${ }^{\circ} \mathrm{C}$ for denaturation and 60 seconds at $60{ }^{\circ} \mathrm{C}$ for annealing and extension.

\section{Sequencing and phylogenetic analysis for MCPyV}

The product of RT-PCR was sequenced by the company BGI (CHINA) and the sequences were then used to draw the phylogenic tree.

\section{RESULTS}

Sixteen $(7.1 \%)$ out of two hundred and twenty five specimens were proved positive to MCPyV. Out of these $3(4.3 \%)$ samples were from Hodgkin and $13(8.4 \%)$ samples were from NonHodgkin lymphoma patients with no significant difference between the two groups (Table1).

According to the gender, MCPyV was detected in $11(8.8 \%)$ male and $5(5 \%)$ female, with no significant difference between the two sexes (Table 3). The frequency of MCPyV positivity was highest in the age group 10-30 years old $(16 \%)$ and lowest in the age group 31-50 (4.3\%) but with no significant differences between the three age groups tested (Table 4).

Nucleotide Sequencing and Phylotyping analysis of Merkle cell polyoma virus:

Sequencing of MCPyV, LT gene was done in eight RT-PCR positive samples of which three samples $(20,58$ and 77$)$ were successfully sequenced and were compared with other reference sequences published in GeneBank (MK561422.1, LC148301.1, MH136801.1 and KX781279.1). The sequences of the three amplified fragments showed $100 \%$ similarity to each other and $100 \%$ identity with the reference sequences (data not shown).

\section{DISCUSSION}

Several epidemiological studies indicated the high frequency of exposure to MCPyV in the human population [14,15], similar to frequencies reported for the other Polyomaviridae members $[16,17]$. It is reported that in most of the cases, the primary infection occurs during childhood but reaching up to $85 \%$ in adulthood according to some researchers $[18,19]$, who reported the occurrence of antibodies against MCPyV antigens in serum samples of healthy adults. 
Table 1. Primers and probes used for the LT regions of MCPyV Real-time PCR.

\begin{tabular}{|c|c|c|c|c|}
\hline No. & $\begin{array}{l}\text { Primer } \\
\text { sets }\end{array}$ & $\begin{array}{l}\text { Nucleotide sequence } \\
\text { position }\end{array}$ & sequence $5^{\prime}-3^{\prime}$ & $\begin{array}{c}\text { PCR amplicons } \\
\text { (bp) }\end{array}$ \\
\hline 1 & LT.1F & $1,034-1,053$ & CCACAGCCAGAGCTCTTCCT & \\
\hline 2 & LT.1R & $1,179-1,157$ & TGGTGGTCTCCTCTCTGCTACTG & 146 \\
\hline 3 & LT. probe & $1,065-1,088$ & $\begin{array}{c}\text { FAM-TCCTTCTCAGCGTCCCAGGCTTCA- } \\
\text { TAMRA }\end{array}$ & \\
\hline
\end{tabular}

Table 2. Frequency of Merkle cell polyoma virus among Hodgkin and Non-Hodgkin lymphoma.

\begin{tabular}{|c|c|c|c|c|}
\hline \multirow{2}{*}{ Lymphoma types } & \multicolumn{2}{|c|}{ Merkle cell polyoma virus } & \multirow{2}{*}{ Total } & \multirow{2}{*}{$P$ value } \\
\hline & Positive & Negative & & \\
\hline Hodgkin & $3(4.3 \%)$ & $67(95.7 \%)$ & $70(31.1 \%)$ & \\
\hline Non-Hodgkin & $13(8.4 \%)$ & $142(91.6 \%)$ & $155(68.9 \%)$ & 0.268 \\
\hline Total & $16(7.1 \%)$ & 209 (92.9\%) & $225(100 \%)$ & \\
\hline
\end{tabular}

Table 3. Total number of positive MCPyV patients according to gender.

\begin{tabular}{|c|c|c|c|}
\hline \multirow{2}{*}{ Sex } & \multicolumn{2}{|c|}{ Merkle cell polyoma virus } & \multirow{2}{*}{ P. value } \\
\hline & Positive & Negative & \\
\hline Male 125 (55.6\%) & $11(8.8 \%)$ & $114(91.2 \%)$ & \\
\hline Female 100 (44.4\%) & $5(5 \%)$ & $95(95 \%)$ & 0.270 \\
\hline Total 225 (100\%) & $16(7.1 \%)$ & 209 (92.9\%) & \\
\hline
\end{tabular}

Table 4. Total number of positive MCPyV patients according to age group.

\begin{tabular}{|c|c|c|c|}
\hline \multirow{2}{*}{ Age group in years (no, tested, \%) } & \multicolumn{2}{|c|}{ Merkle cell polyoma virus } & \multirow[b]{2}{*}{ P. value } \\
\hline & Positive & Negative & \\
\hline $10-30(25,11.1 \%)$ & $4(16 \%)$ & $21(84 \%)$ & \\
\hline $31-50(115,51.1 \%)$ & $5(4.3 \%)$ & $110(95.7)$ & \\
\hline$\geq 51(85,37.5 \%)$ & $7(8.2 \%)$ & $78(91.8 \%)$ & 0.106 \\
\hline Total $(225,100 \%)$ & $16(7.1 \%)$ & $209(92.9 \%)$ & \\
\hline
\end{tabular}


In the present study, the sequences of the amplified fragments showed $100 \%$ similarity to each other and $100 \%$ identity with the reference sequences from gene bank confirming our RTPCR results of MCPyV detection in some of our lymphoma patients.

In the current study 16 out of 225 (7.1\%) specimens were positive for MCPyV, similar results with low prevalence rates were detected using PCR in Non-Hodgkin (6.6\%) and Hodgkin (3.3\%) lymphoma specimens from Canada by Toracchio et al. [10].

However, Pantulu et al., [11] using PCR in Japan reported a prevalence rate of $27 \%$ (32/120) of MCPyV in CLL cases. Other studies using RT-PCR by Haugg et al [15] Goh et al., [19] and by Lam et al. [20] detected 9/27 (33.3\%), 27.1\% (19/70), and 33.3\% (6/18) of MCPyV in CLL cases respectively. The high rates of MCPyV among these CLL cases compared to our results may be due to the limitation of these studies to CLL (one of the lymphoma types) population compared to the wide range of our population which contained many types of lymphoma. In addition, higher MCPyV DNA detection rates have been shown to consistently occur in CLL subjects, although prevalence and viral load are low $[5,10]$.

Our results also indicated no significant differences in the rate of MCPyV detection according to type of disease (Hodgkin vs NonHodgkin); gender (male vs female); or age (Tables 2-4). This is similar to previous studies which found no significant association between gender and age and the prevalence of MCPyV in patients with acute and chronic resoiratory diseases including lung cancer. MCPyV is also known to be a common infection in the general population $[21,22]$.Thus there appears to be an equal opportunity for the virus to be the cause of cancer in different groups(as a part of the general population) of our study population.

In this respect, some limitations of our study comprise the absence of data on insertion sites pattern of the virus in cells of patients. In addition our study also lacks information on presence or absence of $\mathrm{T}$-antigen oncoproteins and viral $\mathrm{T}$-antigen expression in cells of our patients and mutations that might be present in the viral $T$ antigen. These limitations are largely due to limited funds and resources available.

\section{Conclusion}

In conclusion the presence and incidence of MCPyV in lymphoma patients in Sudan, was documented through the molecular detection using RT-PCR and sequencing indicating low prevalence rates among lymphoma patients. Further surveys and molecular investigations at the country level are important in order to fully unravel the true status of MCPyV infection in Sudan.

Finally, this study provides the first evidence that MCPyV exists in a subset of Sudanese lymphoma patients.

\section{ACKNOWLEDGMENTS}

We would like to thank the Central Laboratory of the Ministry of Higher Education and Research Khartoum, Sudan for funding part of my studies.

Competing interests: The authors declare no competing interest.

Funding: The authors received no funding for this study.

\section{REFERENCES}

1. Tamura K, Sawada H, Izumi $\mathrm{Y}$, et al, Kyushu Hematology Organization for Treatment (K-HOT) Study Group: Chronic Lymphocytic leukemia (CLL) is rare, but the proportion of T-CLL is high in Japan. Eur J Haematol 2001, 67:152-157.

2. Gjoerup O, Chang Y: Update on human polyomaviruses and cancer. Adv Cancer Res 2010, 106:1-51.

3. Moens U, Ludvigsen M, Van Ghelue M. Human polyomaviruses in skin diseases. Patholog Res Int 2011; $123491: 12$.

4. Feng $\mathrm{H}$, Shuda $\mathrm{M}$, Chang $\mathrm{Y}$, Moore PS: Clonal integration of a polyomavirus in human Merkle cell carcinoma. Science 2008, 319:1096-1100.

5. Scuda N, Hofmann J, Calvignac-Spencer S, et al. A novel human polyomavirus closely related to the African green monkey-derived lymphotropic polyomavirus. J Virol 2011, 85:4586-4590.

6. Schowalter RM, Pastrana DV, Pumphrey KA, Moyer AL, Buck CB. Merkle cell polyomavirus and two previously unknown polyomaviruses are chronically shed from human skin. Cell Host Microbe 2010, 7:509-515. 
7. ZurHausen A: Opening new roads for MCPyV. Blood 2011, 117:6975-6976

8. Shuda M, Arora R, Kwun HJ, et al. Human Merkle cell polyomavirus infection I. MCV $\mathrm{T}$ antigen expression in Merkle cell carcinoma, lymphoid tissues and lymphoid tumors. Int J Cancer 2009, 125:1243-1249.

9. Tolstov YL, Arora R, Scudiere SC, et al. Lack of evidence for direct involvement of Merkle cell polyomavirus (MCV) in chronic lymphocytic leukemia (CLL). Blood 2010, 115:4973-4974.

10. Toracchio S, Foyle A, Sroller V, et al. Lymphotropism of Merkle cell polyomavirus infection, Nova Scotia, Canada. Emerg Infect Dis 2010, 16:1702-1709.

11. Pantulu ND, Pallasch CP, Kurz AK, et al. Detection of a novel truncating Merkle cell polyomavirus large $\mathrm{T}$ antigen deletion in chronic lymphocytic leukemia cells. Blood 2010, 116:52805284.

12. Haugg AM, Speel EJ, Pantulu ND, et al. Fluorescence in situ hybridization confirms the presence of Merkle cell polyomavirus in chronic lymphocytic leukemia cells. Blood 2011, 117:57765777.

13. Carter JJ, Paulson KG, Wipf GC, et al. Association of Merkel cell polyomavirus-specific antibodies with Merkel cell carcinoma. J Natl Cancer Inst 2009; 101:1510-1522.

14. Faust H, Pastrana DV, Buck CB, Dillner J, Ekström J. Antibodies to Merkel cell polyomavirus correlate to presence of viral DNA in the skin. J Infect Dis 2011; 203:1096-1100.

15. Viscidi RP, Rollison DE, Sondak VK, et al. Agespecific seroprevalence of Merkel cell polyomavirus, $\mathrm{BK}$ virus, and JC virus. Clin Vaccine Immunol 2011; 18:1737-1743.

16. Stolt A, Sasnauskas K, Koskela P, Lehtinen M, Dillner J. :Seroepidemiology of the human polyomaviruses. J Gen Virol 2003; 84: 1499-1504.

17. Touze A, Gaitan J, Arnold F, et al. Generation of Merkel cell polyomavirus (MCV)-like particles and their application to detection of MCV antibodies. J ClinMicrobiol 2010; 48:1767-1770.

18. Nicol JT, Robinot R, Carpentier A, et al. Agespecific seroprevalences of Merkel cell polyomavirus, human polyomaviruses 6, 7, and 9, and Trichodysplasia spinulosa-associated polyomavirus. Clin Vaccine Immunol 2013; 20:363-368.

19. Goh S, Lindau C, Tiveljung-Lindell A, Allander T: Merkel cell polyomavirus in respiratory tract secretions. Emerg Infect Dis 2009; 15: 489-491.

20. Lam WY, Leung BW, Chu IM, et al. Survey for the presence of $\mathrm{BK}, \mathrm{JC}, \mathrm{KI}, \mathrm{WU}$ and Merkel cell polyomaviruses inhuman brain tissues. J ClinVirol 2010; 48:11-14.
21. Kean JM, Rao S, Wang M, Garcea RL (March 2009). Atwood WJ (ed.), "Seroepidemiology of human polyomaviruses". PLoS Pathogens. 5 (3): e1000363. doi:10.1371/journal.ppat.1000363. PMC 2655709. PMID 19325891.

22. Tolstov $\mathrm{YL}$, Pastrana DV, Feng $\mathrm{H}$, et al. Human Merkel cell polyomavirus infection II. MCV is a common human infection that can be detected by conformational capsid epitope immunoassays. International Journal of Cancer 2009; 125 (6): 12501256. 